\title{
Left ventricle restoration in end stage ischemic dilated cardiomyopathy
}

\author{
Z Jonjev \\ From 23rd World Congress of the World Society of Cardio-Thoracic Surgeons \\ Split, Croatia. 12-15 September 2013
}

\section{Background}

Patients with end stage dilated cardiomyopathy exhibit extensive remodeling of the left ventricle, annular dilation, and significant mitral and tricuspid regurgitation. These changes increase perioperative morbidity and mortality, and emphasize patient candidacy for heart transplantation. We previously published that Reductive Annuloplasty of Double (mitral and tricuspid) Orifices could be successfully applied in selective patients. However, it was unclear if implantation of the artificial mitral valve with preservation of native mitral valve could be used as a method in such cases.

\section{Methods}

There were 16 patients (13 males, 3 females) with ischemic dilated cardiomyopathy, mean ejection fraction below $30 \%(26.6 \pm 3.1 \%)$, and mean left ventricle end-diastolic internal diameter greater than $7.0 \mathrm{~cm}(7.3 \pm 0.3 \mathrm{~cm})$ with coaptation depth of the mitral valve (tenting area) significantly lower than $1.1 \mathrm{~cm}$. In addition to myocardial revascularization mechanical or biological artificial valve were implanted in 12 and 4 patients respectively. Modified De Vega tricuspid annuloplasty was performed in all patients.

\section{Results}

There was no postoperative 30-day mortality. Survival rate after 5 years was $93.75 \%$.

\section{Conclusion}

Reverse remodeling of the left ventricle by CABG surgery followed with implantation of the artificial mitral valve and tricuspid suture annuloplasty could be successfully applied in selective patients with ischemic dilative

Correspondence: jonjevz@nscable.net

Institute for CVD of Vojvodina, Sremska Kamenica, Serbia cardiomyopathy. Our method should not be recognized as a valve repair, but ventricular repair procedure also.

Published: 11 September 2013

doi:10.1186/1749-8090-8-S1-0147

Cite this article as: Jonjev: Left ventricle restoration in end stage ischemic dilated cardiomyopathy. Journal of Cardiothoracic Surgery 2013 8(Suppl 1):0147.
Submit your next manuscript to BioMed Central and take full advantage of:

- Convenient online submission

- Thorough peer review

- No space constraints or color figure charges

- Immediate publication on acceptance

- Inclusion in PubMed, CAS, Scopus and Google Scholar

- Research which is freely available for redistribution
() Biomed Central 